\title{
Importance of Microglial Cytoskeleton and the Actin-interacting Proteins in Alzheimer's Disease
}

\author{
Go-Eun Choi ${ }^{\dagger}$ ** \\ Department of Clinical Laboratory Science, College of Health Sciences, \\ Catholic University of Pusan, Busan 46252, Korea
}

\begin{abstract}
Alzheimer's disease (AD) is the most common neurodegenerative disorder and is expected to become more and more widespread as life expectancy increases. New therapeutic target, as well as the identification of mechanisms responsible for pathology, is urgently needed. Recently, microglial actin cytoskeleton has been proposed as a beneficial role in axon regeneration of brain injury. This review highlights in understanding of the characteristics of microglial actin cytoskeleton and discuss the role of specific actin-interacting proteins and receptors in $\mathrm{AD}$. The precise mechanisms and functional aspects of motility by microglia require further study, and the regulation of microglial actin cytoskeleton might be a potential therapeutic strategy for neurological diseases.
\end{abstract}

Key Words: Alzheimer's disease, Microglia, Cytoskeleton, Actin filaments, Ionized calcium binding adapter molecules (Iba1), Cofilin 1 (CFL1)

\section{INTRODUCTION}

Alzheimer's disease is the most common neurodegenerative disorder and is characterized. Alzheimer's disease is expected to become more widespread as life expectancy increases, so urgent need for new therapeutic targets as well as the identification of mechanisms responsible for pathology. Over the past decade, two major functions of $\mathrm{AD}$, early amyloid- $\beta(\mathrm{A} \beta)$ plaques and nerve fiber tangles (NFT), have been intended to provide insight into $\mathrm{AD}$ etiology. However, a number of investigations initially demonstrated that in addition to $\mathrm{A} \beta$ plaques and NFT, the brains of patients with $\mathrm{AD}$ showed evidence of a persistent inflammatory response (Akama et al., 2000; Akiyama et al., 2000; Combs et al., 2000; Tuppo and Arias, 2005; Mrak and Griffin, 2007). Several studies have shown an inflammatory response in post-mortem tissue samples of AD patients (Cribbs et al., 2012; Sudduth et al., 2013; Gomez-Nicola and Boche, 2015; Janssen et al., 2016; Knezevic and Mizrahi, 2018). Unlike acute inflammation, the anti-inflammatory and pre-inflammatory responses of $\mathrm{AD}$ are characterized by chronic inflammation, which occurs when the signal transmission balance is broken (Grammas, 2011; Rubio-Perez and Morillas-Ruiz, 2012; Meraz-Ríos et al., 2013; Ferreira et al., 2014). This chronic inflammation is due to the activation of microglia, moves and accumulates at the site of injury (Mittelbronn et al., 2001; Nimmerjahn et al., 2005; Ginhoux et al., 2010).

Recently, a number of papers have focused on microglial function of inflammatory cytokines, and chemokines. How-

Received: February 12, 2020 / Accepted: March 21, 2020

*Professor.

${ }^{\dagger}$ Corresponding author: Go-Eun Choi. Department of Clinical Laboratory Science, College of Health Sciences, Catholic University of Pusan, Busan 46252, Korea.

Tel: +82-51-510-0563, Fax:+82-51-510-0568, e-mail: gechoi@cup.ac.kr

(C) The Korean Society for Biomedical Laboratory Sciences. All rights reserved.

(c) This is an Open Access article distributed under the terms of the Creative Commons Attribution Non-Commercial License (http://creativecommons.org/licenses/by-nc/3.0/) which permits unrestricted non-commercial use, distribution, and reproduction in any medium, provided the original work is properly cited. 


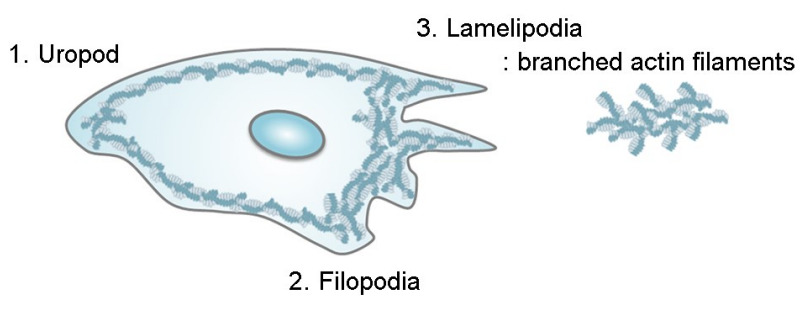

Actin structure in amoeboid microglia

Fig. 1. Representation of the vairous actin structures present in microglia. The cells reconstruct the actin filaments to form structures such as urapods (1), filopodia (2), and lamelopodia (3). Lamellipodia is containing branched actin filaments, which form the the mechanism of the actin network to easily connect with each other forming an intricate and highly plastic network.

ever, studies on dynamics of microglial actin cytoskeleton are rare. Recently, microglial actin cytoskeleton has been proposed as a beneficial role in brain injury through axon regeneration. This review highlights in understanding of the characteristics of microglial actin cytoskeleton in $\mathrm{AD}$ and discuss the factors that influence receptors and signaling pathways. In addition, the relative contribution by resident microglia during disease processes is also considered.

\section{Morphological change for the mobility of microglia}

Microglia has the ability to change shape. The ability allows for high mobility in tight spaces within the brain parenchyma and the feeding of various particles to adapt to the environment. The morphological change is the result of rearrangement of cytoskeletal proteins, in particular actin filaments. For motility and mobility, the cells reconstruct the actin filaments to form structures such as lamelopodia, filopodia and urapods (Fig. 1).

Lamellipodia is a very thin cytoplasmic membrane, containing a densely packed actin filament network arranged below the membrane. "Filopodia" plays an important role in intercellular signal transduction, chemical attraction and adhesion to the extracellular matrix. The structure called "uropod" attracts the rest of the cell body. The uropod is the posterior part of the cell formed by contractile trailing protrusions (Gupton and Gertler, 2007; Lai et al., 2008; Blanchoin et al., 2014; Hind et al., 2016; Franco-Bocanegra et al., 2019).

Actin filaments (F-actin) are the basic components of the actin cytoskeletal structure formed by the polymerization of spherical actin monomers (G-actin). The mechanism of F-actin formation in microglia is assembly, branching, crosslinking and degradation with other proteins. Actin polymers are produced by combinations of complex branch networks. Branching of F-actin plays an essential role in motility and mobility for the actin network (Vinzenz et al., 2012).

\section{Mechanisms of microglial actin network}

Polymers of F-actin interact with other proteins through crosslinking mechanisms to control motility and mobility. The crosslinking mechanism is a more complex structure than the actin network and is formed of actin filaments that allow for adaptability. Several crosslinked proteins have been reported that are specifically expressed depending on the cell type. The microglia involved in actin bundling and membrane ruffling with ionized calcium binding adapter molecules (Iba1) (Ohsawa et al., 2000). Actin bundles support the structures, such as lamellipodia and filopodia, which are structures essential for migration and phagocytosis of microglia (Bartles, 2000; Sasaki et al., 2001; Ohsawa et al., 2004).

Other cross-linking protein expressed by microglia, Cofilin 1 (CFL1) which serves as disassembly machinery in microglia. In order to respond to changes in the environment, the cross-linked proteins continue to carry out the mechanism of assembly as well as degradation. CFL1 is an actin-binding protein that cleaves the polymerization of actin filaments, and in this way produces G-actin monomers for filament elongating and branching. CFL1 is an important regulator of actin dynamics and is highly expressed in the human brain (Niwa et al., 2002; Samstag et al., 2013). A study has shown that CFL1 knockdown inhibits activation and migration of microglia (Alhadidi and Shah, 2018), which highlights the importance of CFL1 in microglial function.

\section{Association with signaling pathways of phagocytosis}

Specific receptors and signal transduction pathways contribute to the reconstitution of actin proteins are utilized for microglial phagocytosis (Fig. 2). In addition, phagocytosis of microglia may require several types of receptors to function (Fu et al., 2014). In general, there are highly affinity recep- 


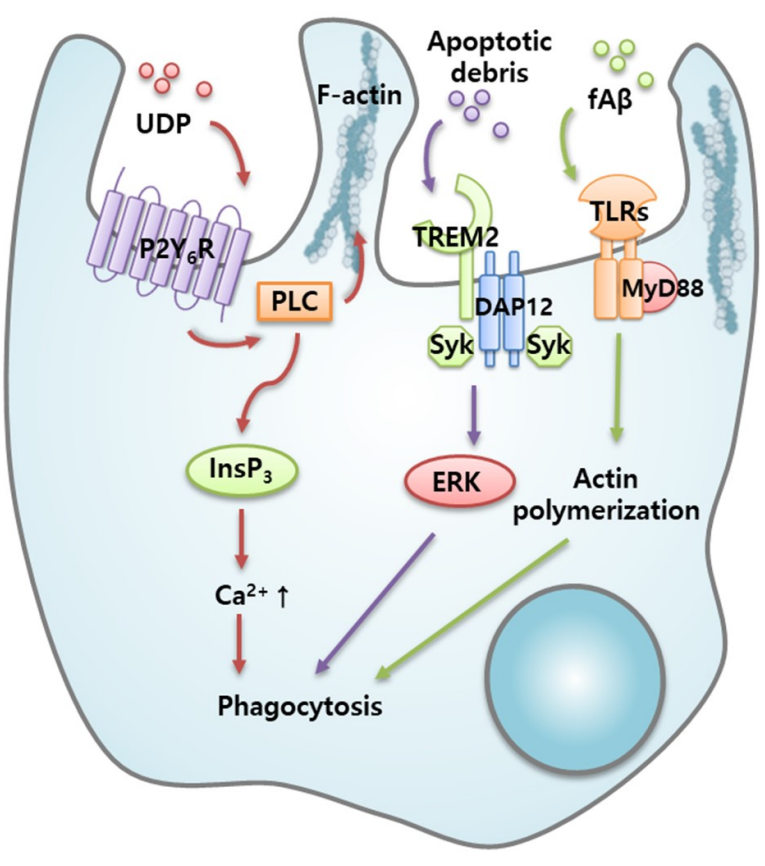

Fig. 2. Microglial phagocytosis and signal pathways associated with actin cytoskeleton in Alzheimer's disease. UDP trigger microglial phagocytosis through $\mathrm{P}_{2} \mathrm{Y}_{6} \mathrm{R} / \mathrm{PLC} / \mathrm{InsP} 3$ pathway. Apoptotic debris induces phagocytosis via TREM-2/DAP12/ERK pathway. $\mathrm{f}-\mathrm{A} \beta$ provokes phagocytosis by microglia via TLRs through activation of MyD88-dependent actin polymerization.

tors that bind to external microbial pathogens, such as Tolllike receptors (TLRs) and recognized apoptotic cell substances, such as Trigger Receptors Expressed on Myeloid cells 2 (TREM-2).

TREM-2 is located primarily on the cell surface of microglial cells of bone and central nerve system (CNS), upregulating chemokine synthesis and mediating protective phagocytosis of apoptotic cell debris (Klesney-Tait et al., 2006; Napoli and Neumann, 2010). TREM-2 in microglial cells leads to the reconstitution of F-actin and phosphorylation of extracellular signal regulated kinase (ERK) / mitogen activated protein kinase (MAPK) through binding to DNAX activating protein 12 (DAP12) to mediate the removal of apoptotic neurons (Takahashi et al., 2005; Piccio et al., 2007). Clinical observation shows that TREM-2 / DAP12 aberrant signal transmission due to genetic mutations of TREM-2 and DAP12 results in Nasu-Hakola disease, a systemic osteocystic disease with progressive sporadic dementia and extensive sclerosis in the systemic frontal and basal ganglia
(Satoh et al., 2012).

Besides these two receptors, some receptors, including the complement receptor (Veerhuis et al., 2011), scavenger receptor, pyriminergic receptor P2Y G-protein binding 6 ( $\left.\mathrm{P} \mathrm{Y}_{6}\right)$, macrophage antigen complex 2, mannose receptors (Lucin and Wyss-Coray, 2009), and low density lipoprotein receptor-related protein receptors are involved in phagocytosis in brain inflammatory responses (Smith, 1999).

In particular, research on the $\mathrm{P}_{2} \mathrm{Y}_{6}$ receptor has attracted attention over the past few years since the demonstration that $\mathrm{P} \mathrm{Y}_{6}$ receptors induce uridine diphosphate (UDP)-induced microglial phagocytosis (Koizumi et al., 2007; Uesugi et al., 2012). $\mathrm{P} 2 \mathrm{Y}_{6}$ receptors actively respond to UDP and activate phospholipase $\mathrm{C}$ to induce the synthesis of inositol 1,4,5-triphosphate and to release $\mathrm{Ca}^{2+}$ (Koizumi et al., 2007). In addition to causing intracellular $\mathrm{Ca}^{2+}$ overloading, the $\mathrm{P}_{2} \mathrm{Y}_{6}$ receptor dependent signaling pathway promotes actin cytoskeletal polarization to form filopodia-like protrusions, thereby promoting cell phagocytosis.

\section{The role of actin-interacting protein in AD progression}

Overall, the changes in microglial morphology have been noted presence of $\mathrm{AD}$ pathology, as evidenced in post mortem human brain. To observe the relationship between phenotype of microglia and disease progression in $\mathrm{AD}$, the post mortem human brain study compared with morphology and number of microglia in various brain areas including the temporal cortex, and frontal cortex (Hopperton et al., 2018). The author of the study considered that the temporal cortex affected early $\mathrm{AD}$, after which the frontal cortex was affected.

A reduced number of Iba1-positive microglia was observed in the temporal cortex, as well as an overall lower number of microglia. The activated form of ramified microglia was reported only in the visual cortex, indicating that microglia was activated during the early stages of AD. Therefore, it can be seen that microglia in the visual cortex are associated with tau pathology and have an inverse relationship between ramified microglia and arborized area.

In microglia, actin-interacting proteins can potentially play a role in aging and AD progression. Phosphorylated tau and co-localized CFL1-actin rods caused abnormal accu- 
mulation and aggregation of F-actin (Fulga et al., 2007). Because tau is also a microtubule protein, tau hyperphosphorylation causes cytoskeletone dysfunction, which can also cause difficulties in regulating actin dynamics. In animal study, a reduction in levels of activated CFL1 was observed in an age-dependent manner in APPPS1 mice and exceeded those seen in aging in wild-type mice. This suggests that AD progress is associated with an increase in phosphorylated CFL1 (Hinman et al., 2004).

\section{Microglial receptors and signaling pathways in $\mathrm{AD}$ di- sease}

AD pathology utilized the APP/PS1 and 5XFAD transgenic mouse models of A $\beta$ pathology along with human $\mathrm{AD}$ brain tissues (Ulrich et al., 2014; Jay et al., 2015). Initial characterization of TREM2 in AD revealed the contribution of tau pathology using hTau mice (Bemiller et al., 2017). This exacerbation is accompanied by morphological dystrophy and extensive neurological stress kinase hyperactivation including ERK, c-Jun N-terminal kinase (JNK) and Glycogen synthase kinase $3 \beta$ (GSK3 $\beta$ )-related pathways. TREM2 signal transduction in the context of amyloid pathology appears to have a disease-specific contribution of TREM2. Generally, they are protected at an early stage of the disease by promoting the removal of intracellular and extracellular pathological tau species and damaged neuronal debris. Inflammation and abnormal synapse and neuron swallowing, however, become pathogenic during the neurodegenerative stage of the prevailing disease (Leyns et al., 2017). In the study, the authors further emphasized the heterogeneity of TREM2 involved in the neurodegenerative process by the stage-specific response to pathology.

The role of the $\mathrm{P}_{2} \mathrm{Y}_{6}$ receptor, a member of the G-proteincoupled receptor family, in $\mathrm{AD}$ has been investigated recently in several studies using animal models and post-mortem human brain (Lai et al., 2008; Ajit et al., 2013). Deletion of the $\mathrm{P} 2 \mathrm{Y}_{6} \mathrm{R}$ in a mouse model of $\mathrm{AD}$ increases the mortality, enhances neurological deficits and $A \beta$ accumulation in the brain and decreases the migration of microglia to $A \beta$ plaques (Ajit et al., 2013). Similarly, reduced $\mathrm{P} 2 \mathrm{Y}_{6} \mathrm{R}$ expression in microglia but also in astrocytes has been observed in postmortem brain samples from $\mathrm{AD}$ patients, as compared to normal controls, suggesting that loss of $\mathrm{P}_{2} \mathrm{Y}_{6} \mathrm{R}$ expression in microglia correlates with the $\mathrm{AD}$ progression in humans (Lai et al., 2008). These results suggest that $\mathrm{P}_{2} \mathrm{Y}_{6} \mathrm{R}$ in microglia can prevent the progression of $\mathrm{AD}$, particularly under neuroinflammatory conditions (Elliott et al., 2009).

\section{CONCLUSIONS}

Microglia, resident macrophages of the CNS, plays an important role in the pathological and physiological processes of the AD disease. Microglial cells are involved in several functions of the brain. Changes in cell motility and shape are associated with functional changes in the cell. Motility and mobility are determined by a number of actin interacting proteins and membrane receptors. $\mathrm{AD}$ has been found to change actin-interacting proteins, likely reflecting changes in motility of microglia, which may contribute to the development and progression of the AD disease. The current collected research has clearly identified the relationship between actin protein and tau. However, due to the relative lack of research on microglia motility proteins in $\mathrm{AD}$, related studies are needed. This review also highlights in understanding of the role of specific actin-interacting proteins and receptors in aging and $\mathrm{AD}$. The precise mechanisms and functional aspects of motility by microglia require further study, and the regulation of microglial actin cytoskeleton might be a potential therapeutic strategy for neurological diseases.

\section{ACKNOWLEDGEMENT}

This study was supported by research fund of Catholic University of Pusan 2018.

\section{CONFLICT OF INTEREST}

The authors declare that they have no conflict of interest.

\section{REFERENCES}

Ajit D, Woods LT, Camden JM, Thebeau CN, El-Sayed FG, Greeson GW, Erb L, Petris MJ, Miller DC, Sun GY, Weisman GA. Loss of P2Y Nucleotide Receptors Enhances Early Pathology in the TgCRND8 Mouse Model of Alzheimer's 
Disease. Mol Neurobiol. 2013. 49: 1031-1042.

Akama KT, Eldik LJV. b-Amyloid Stimulation of Inducible Nitricoxide Synthase in Astrocytes Is Interleukin-1b- and Tumor Necrosis Factor-a (TNFa)-dependent, and Involves a TNFa Receptor-associated Factor- and NFkB-inducing Kinasedependent Signaling Mechanism. J Biol Chem. 2000. 275: 7918-7924.

Akiyama H, Barger S, Barnum S, Bradt B, Bauer J, Cole GM, Cooper NR, Eikelenboom P, Emmerling M, Fiebich BL, Finch CE, Frautschy S, Griffin WST, Hampel H, Hull M, Landreth G, Lue LF, Mrak R, Mackenzie IR, McGeer PL, O'Banion MK, Pachter J, Pasinetti G, Plata-Salaman C, Rogers J, Rydel R, Shen Y, Streit W, Strohmeyer R, Tooyoma I, Muiswinkel FLV, Veerhuis R, Walker D, Webster S, Wegrzyniak B, Wenk G, Wyss-Coray T. Inflammation and Alzheimer's disease. Neurobiol Aging. 2000. 21: 383-421.

Alhadidi Q, Shah ZA. Cofilin mediates lps-induced microglial cell activation and associated neurotoxicity through activation of nf-kb and jak-stat pathway. Mol Neurobiol. 2018. 55: 1676 -1691 .

Bartles JR. Parallel actin bundles and their multiple actin-bundling proteins. Curr Opin Cell Biol. 2000. 12: 72-78.

Blanchoin L, Boujemaa-Paterski R, Sykes C, Plastino J. Actin dynamics, architecture, and mechanics in cell motility. Physiol Rev. 2014. 94: 235-263.

Bemiller SM, McCray TJ, Allan K, Formica SV, Xu G, Wilson G, Kokiko-Cochran ON, Crish SD, Lasagna-Reeves CA, Ransohoff RM, Landreth GE, Lamb BT. TREM2 deficiency exacerbates tau pathology through dysregulated kinase signaling in a mouse model of tauopathy. Mol Neurodegener. 2017. 74.

Combs CK, Johnson DE, Karlo JC, Cannady SB, Landreth GE. Inflammatory mechanisms in Alzheimer's disease: Inhibition of b-Amyloid-Stimulated proinflammatory responses and neurotoxicity by PPARg agonists. J Neurosci. 2000. 20: 558 $-567$.

Cribbs DH, Berchtold NC, Perreau V, Coleman PD, Rogers J, Tenner AJ, Cotman CW. Extensive innate immune gene activation accompanies brain aging, increasing vulnerability to cognitive decline and neurodegeneration: a microarray study. J Neuroinflammation. 2012. 9: 179.

Elliott MR, Chekeni FB, Trampont PC, Lazarowski ER, Kadl A, Walk SF, Park D, Woodson RI, Ostankovich M, Sharma P, Lysiak JJ, Harden TK, Leitinger N, Ravichandran KS. Nucleotides released by apoptotic cells act as a find-me signal to promote phagocytic clearance. Nature. 2009. 461: 282-286.

Franco-Bocanegra DK, McAuley C, Nicoll JAR, Boche D. Molecular Mechanisms of Microglial Motility: Changes in Ageing and Alzheimer's Disease. Cells. 2019. 8: 693.

Ferreira ST, Clarke JR, Bomfim TR, De Felice FG. Inflammation, defective insulin signaling, and neuronal dysfunction in Alzheimer's disease. Alzheimers Dement. 2014. 10: S76-83.

Fu R, Shen Q, Xu P, Luo JJ, Tang Y. Phagocytosis of Microglia in the Central Nervous System Diseases. Mol Neurobiol. 2014. 49: 1422-1434.

Fulga TA, Elson-Schwab I, Khurana V, Steinhilb ML, Spires TL, Hyman BT, Feany MB. Abnormal bundling and accumulation of f-actin mediates tau-induced neuronal degeneration in vivo. Nat Cell Biol. 2007. 9: 139.

Ginhoux F, Greter M, Leboeuf M, Nandi S, See P, Gokhan S, Mehler MF, Conway SJ, Ng LG, Stanley ER. Fate mapping analysis reveals that adult microglia derive from primitive macrophages. Science. 2010. 330: 841-845.

Gomez-Nicola D, Boche D. Post-mortem analysis of neuroinflammatory changes in human Alzheimer's disease. Alzheimers Res Ther. 2015. 7.

Grammas P. Neurovascular dysfunction, inflammation and endothelial activation: Implications for the pathogenesis of Alzheimer's disease. J Neuroinflammation. 2011. 8: 26.

Gupton SL, Gertler FB. Filopodia: The fingers that do the walking. Sci STKE. 2007. 400: re5.

Hind LE, Vincent WJ, Huttenlocher A. Leading from the back: The role of the uropod in neutrophil polarization and migration. Dev Cell. 2016. 38: 161-169.

Hinman JD, Duce JA, Siman RA, Hollander W, Abraham CR. Activation of calpain-1 in myelin and microglia in the white matter of the aged rhesus monkey. J Neurochem. 2004. 89: 430-441.

Hopperton KE, Mohammad D, Trépanier MO, Giuliano V, Bazinet RP. Markers of microglia in post-mortem brain samples from patients with Alzheimer's disease: a systematic review. Mol Psychiatry. 2018. 23: 177-198

Janssen B, Vugts DJ, Funke U, Molenaar GT, Kruijer PS, van Berckel BNM, Lammertsma AA, Windhorst AD. Imaging of neuroinflammation in Alzheimer's disease, multiple sclerosis and stroke: Recent developments in positron emission tomography. Biochim Biophys Acta. 2016. 1862: 425-441.

Jay TR, Miller CM, Cheng PJ, Graham LC, Bemiller S, Broihier ML, Xu G, Margevicius D, Karlo JC, Sousa GL, Cotleur AC, Butovsky O, Bekris L, Staugaitis SM, Leverenz JB, Pimplikar 
SW, Landreth GE, Howell GR, Ransohoff RM, Lamb BT. TREM2 deficiency eliminates TREM21 inflammatory macrophages and ameliorates pathology in Alzheimer's disease mouse models. J Exp Med. 2015. 212: 287-295.

Klesney-Tait J, Turnbull IR, Colonna M. The TREM receptor family and signal integration. Nat Immunol. 2006. 7: 1266 -1273 .

Knezevic D, Mizrahi R. Molecular imaging of neuroinflammation in Alzheimer's disease and mild cognitive impairment. Prog Neuropsychopharmacol Biol Psychiatry. 2018. 80: 123-131.

Koizumi S, Shigemoto-Mogami Y, Nasu-Tada K, Shinozaki Y, Ohsawa K, Tsuda M, Joshi BV, Jacobson KA, Kohsaka S, Inoue $\mathrm{K}$. UDP acting at $\mathrm{P}_{2} \mathrm{Y}_{6}$ receptors is a mediator of microglial phagocytosis. Nature. 2007. 446: 1091-1095.

Lai FP, Szczodrak M, Block J, Faix J, Breitsprecher D, Mannherz HG, Stradal TE, Dunn GA, Small JV, Rottner K. Arp2/3 complex interactions and actin network urnover in lamellipodia. EMBO J. 2008. 27: 982-992.

Lai MK, Tan MG, Kirvell S, Hobbs C, Lee J, Esiri MM, Chen CP, Francis PT. Selective loss of P2Y2 nucleotide receptor immunoreactivity is associated with Alzheimer's disease neuropathology. J Neural Transm. 2008. 115: 1165-1172.

Leyns CEG, Ulrich JD, Finn MB, Stewart FR, Koscal LJ, Remolina Serrano J, Robinson GO, Anderson E, Colonna M, Holtzman DM. TREM2 deficiency attenuates neuroinflammation and protects against neurodegeneration in a mouse model of tauopathy. Proc Natl Acad Sci. 2017. 14: 1524-1529.

Lucin KM, Wyss-Coray T. Immune activation in brain aging and neurodegeneration: too much or too little? Neuron. 2009. 64: 110-122.

Meraz-Ríos MA, Toral-Rios D, Franco-Bocanegra D, VilledaHernández J, Campos-Peña V. Inflammatory process in Alzheimer's Disease. Front Integr Neurosci. 2013. 7.

Mrak RE, Griffin WST. Common inflammatory mechanisms in Lewy Body disease and Alzheimer disease. J Neuropathol Exp Neurol. 2007. 66: 683-686.

Mittelbronn M, Dietz K, Schluesener HJ, Meyermann R. Local distribution of microglia in the normal adult human central nervous system differs by up to one order of magnitude. Acta Neuropathol. 2001. 101: 249-255.

Napoli I, Neumann H. Protective effects of microglia in multiple sclerosis. Exp. Neurol. 2010. 225: 24-28.

Nimmerjahn A, Kirchho F, Helmchen F. Resting microglial cells are highly dynamic surveillants of brain parenchyma in vivo. Science. 2005. 308: 1314-1318.
Niwa R, Nagata-Ohashi K, Takeichi M, Mizuno K, Uemura T. Control of actin reorganization by slingshot, a family of phosphatases that dephosphorylate adf/cofilin. Cell. 2002. 108: 233 $-246$.

Ohsawa K, Imai Y, Sasaki Y, Kohsaka S. Microglia/macrophagespecific protein ibal binds to fimbrin and enhances its actinbundling activity. J Neurochem. 2004. 88: 844-856.

Ohsawa K, Imai Y, Kanazawa H, Sasaki Y, Kohsaka S. Involvement of ibal in membrane ruffling and phagocytosis of macrophages/microglia. J Cell Sci. 2000. 113: 3073.

Piccio L, Buonsanti C, Mariani M, Cella M, Gilfillan S, Cross AH, Colonna M, Panina-Bordignon P. Blockade of TREM-2 exacerbates experimental autoimmune encephalomyelitis. Eur J Immunol. 2007. 37: 1290-1301.

Rubio-Perez JM, Morillas-Ruiz JM. A Review: Inflammatory process in Alzheimer's disease, role of cytokines. Scientific World Journal. 2012: 756357

Sasaki Y, Ohsawa K, Kanazawa H, Kohsaka S, Imai Y. Iba1 is an actin-cross-linking protein in macrophages/microglia. Biochem Biophys Res Commun. 2001. 286: 292-297.

Samstag Y, John I, Wabnitz GH. Cofilin: A redox sensitive mediator of actin dynamics during t-cell activation and migration. Immunol Rev. 2013. 256: 30-47.

Satoh J, Tabunoki H, Ishida T, Yagishita S, Jinnai K, Futamura N, Kobayashi M, Toyoshima I, Yoshioka T, Enomoto K, Arai N, Saito Y, Arima K. Phosphorylated Syk expression is enhanced in Nasu-Hakola disease brains. Neuropathology. 2012. 32: 149-157.

Smith ME. Phagocytosis of myelin in demyelinative disease: a review. Neurochem Res. 1999. 24: 261-268.

Sudduth TL, Schmitt FA, Nelson PT, Wilcock DM. Neuroinflammatory phenotype in early Alzheimer's disease. Neurobio Aging. 2013. 34: 1051-1059.

Takahashi K, Rochford CD, Neumann H. Clearance of apoptotic neurons without inflammation by microglial triggering receptor expressed on myeloid cells-2. J Exp Med 2005. 201: 647-657.

Tuppo EE, Arias HR. The role of inflammation in Alzheimer's disease. Int J Biochem Cell Biol. 2005. 37: 289-305.

Uesugi A, Kataoka A, Tozaki-Saitoh H, Koga Y, Tsuda M, Robaye $\mathrm{B}$, Boeynaems JM, Inoue K. Involvement of protein kinase $\mathrm{D}$ in uridine diphosphate-induced microglial macropinocytosis and phagocytosis. Glia. 2012. 60: 1094-1105.

Ulrich JD, Finn MB, Wang Y, Shen A, Mahan TE, Jiang H, Stewart FR, Piccio FR, Colonna M, Holtzman DM. Altered microglial 
response to A beta plaques in APPPS1-21 mice heterozygous for TREM2. Mol Neurodegener. 2014. 20.

Veerhuis R, Nielsen HM, Tenner AJ. Complement in the brain. Mol Immunol. 2011. 48: 1592-1603.

Vinzenz M, Nemethova M, Schur F, Mueller J, Narita A, Urban E, Winkler C, Schmeiser C, Koestler SA, Rottner K, Resch GP, Maeda Y, Small JV. Actin branching in the initiation and maintenance of lamellipodia. J Cell Sci. 2012. 125: 2775
-2785 .

https://doi.org/10.15616/BSL.2020.26.1.1

Cite this article as: Choi GE. Importance of Microglial Cytoskeleton and the Actin-interacting Proteins in Alzheimer's Disease. Biomedical Science Letters. 2020. 26: 1-7. 